УДК 338.48-44(100:477)

\title{
РОЗВИТОК МІЖНАРОДНОГО ТУРИЗМУ УКРАЇНИ ВІД НАЙДАВНІШИХ ЧАСІВ ДО СЬОГОДЕННЯ
}

\author{
Степан КУЗИК \\ Львівський національний університет імені Івана Франка \\ кафедра економічної і соціальної географії \\ вул. П. Дорошенка, 41, Львів, 79000, Україна \\ e-mail: borsukurij2@gmail.com
}

Розглянуто туризм як важливу сферу господарської діяльности країни. Студії констатують, що в сфері туризму виробляється до $8 \%$ ВВП. Це складає майже $1 / 5$ торговельного обігу України. Галузь, що формується, забезпечує роботою тепер майже два мільйони українців.

Туризм в Україні пройшов тривалий період розвитку - від зародження прототипу міжнародного туризму, пов'язаного зі стихійним мандрівництвом, що сягає раннього середньовіччя, до організованого масового туризму XX-XXI ст. Подальшому розвитку міжнародного туризму в Україні сприяє наявна ресурсна база: бальнеологічні ресурси, бальнеогрязеві, фітолікувальні, біотичні, ландшафтні, пляжні ресурси. Важливим засобом розвитку міжнародного туризму вважаються пізнавальні ресурси (пам'ятки історії, історикоархітектурні пам'ятки, пам'ятки сучасної архітектури, унікальні споруди культури, ремесел, пам'ятки фольклору тощо).

Україна, як держава 3 потужною та унікальною туристично-рекреаційною базою, $є$ конкурентоспроможною на світовому ринку туристичних послуг.

Ключові слова: мандрівництво, міжнародний туризм, туристичне районування, туристичні потоки.

Туризм став важливим чинником загального поступу економіки будь-якої країни світу. Одні з них продовжують вдосконалювати традиційні туристичні послуги в головних туристичних регіонах, приваблюючи додаткові потоки відпочивальників, натомість інші потребують значних інвестиційних вкладень, щоб підсилити атрактивність новостворених територій та відповідних туристичних поєднань. Для всіх країн міжнародний туризм відіграє важливу роль у формуванні ВВП, активізації зовнішньоторговельного балансу, створює додаткові робочі місця, сприяє активному розвитку суміжних із ним галузей економіки. Не є винятком Україна, яка за кількістю міжнародних прибуттів входить до 20-ти найрозвиненіших туристичних країн світу, займаючи 17 місце (2016). Такій популярності країни сприяють високоатрактивні туристичні ресурси, які у багатьох випадках вважаються унікальними. Про це писали у своїх розвідках С. Рудницький, О. Киселевська, О. Степанів, В. Кубійович, В. Огоновський. 3поміж сучасних українських вчених, які зробили вагомий науковий внесок у розвиток туризму, вирізняються М. Крачило, І. Твердохлебов, О. Любіцева, М. Мальська, В. Руденко, О. Заставецька, А. Бовсуновська, Я. Олійник, В. Смирнов, П. Масляк, І. Яковенко, О. Шаблій, В. Стафійчук, О. Малиновська, 
ISSN 2078-6077. Наукові зошити історичного факультету Львівського університету. 2018-2019. Випуск 19-20. Proceedings of History Faculty of Lviv University. 2018-2019. Issue 19-20.

М. Рутинський, І. Смаль, І. Філенко, М. Орлова, С. Юрченко, О. Юрченко та iH.

Україна, займаючи вигідне геотуристичне положення, завжди була популярною та цікавою для представників світового мандрівництва. Їх дивувало унікальне природне середовище, традиції, звичаї народу, що заселяв територію сучасної України. Надійною ресурсною базою для розвитку сучасного туризму в Україні стали природні ознаки (кліматичні умови, ландшафтні особливості, мінеральні води та ін.), а також високий історико-культурний потенціял, який захоплює і притягує міжнародних туристів.

Подальше вдосконалення туристичної інфраструктурної бази, сфери обслуги дає підстави стверджувати про високі можливості розвитку і внутрішнього, $\mathrm{i}$ міжнародного туризму в Україні.

Міжнародний туризм в Україні пройшов етапи (стадії) розвитку аналогічно до світових тенденцій ${ }^{1}$.

Периий eman - зародження прототипу міжнародного туризму в Україні, пов'язаного з мандрівництвом. У збережених давноминулих спогадах на особливу увагу заслуговують описи території України, які допомагають оцінити природний потенціял нашої прабатьківщини. Скажімо, Геродот у четвертій книзі дев'ятитомної “Історіі” так описує територію тогочасної України: “Їхня країна рівнинна: рясніє травою і зрошується водою багатьох річок, яких стільки, скільки каналів у Єгипті... Навколо Бористена найкращі і найбільш споживні пасовища для худоби, i дуже багато в ньому риби, приємної на смак, і вода в ньому дуже чиста..., і ниви навколо нього чудові, а там, де не сіяно, виростає висока трава. А в його гирлі відкладається багато солі. І великі риби в ньому без колючок і кісток"2.

У сімнадцятитомовій праці “Географія” Страбон описує життя і побут племен Північного та Східного Причорномор'я, їхнє господарство, відображає чинні тоді зв'язки з давньогрецькими містами. Найбільше відомостей він подає про Босфор і Херсонес.

Писемні джерела часів Київської Русі засвідчують, що Україна-Русь була багатою державою: мала, як на цей період, розвинуте сільське господарство (хліборобство, садівництво, бджільництво, ремесло і промисли), що дивувало чужоземних гостей, котрі заїжджали на ці землі.

Вагоме місце у житті й обороні краю посідали давньоруські міста, які були переважно не лише ремісничо-торговельними осередками, а й адміністративнополітичними центрами окремих земель. Саме до них належав Київ - столиця Руси-України. У літописі “Повість минулих літ" налічується в IX-X ст. 20 міст, у тому числі Чернігів, Переяслав, Любеч, Вишгород та ін. У Х ст. літописці

\footnotetext{
${ }^{1}$ Степан Кузик, Теоретичні проблеми туризму: суспільно-географічний підхід: монографія. (Львів: Видавничий центр ЛНУ ім. Івана Франка, 2010), 89-101.

${ }^{2}$ Степан Макарчук, Джерелознавство історії Украӥни. (Львів: Світ, 2008), 47.
} 
ISSN 2078-6077. Наукові зошити історичного факультету Львівського університету. 2018-2019. Випуск 19-20. Proceedings of History Faculty of Lviv University. 2018-2019. Issue 19-20.

згадують 32 міста, у XI ст. - приблизно 60, а в XIII ст. їх кількість сягнула майже 300. У XII-XIII ст. великими містами вважалися Київ, Володимир, Галич, Львів та ін.

У XIV-XV ст. (період урбанізації Европи) Київ відігравав значну роль у господарському житті Центрально-Східної Европи. У цей час на західних землях зростало значення Львова як ремісничого, адміністративного й оборонного центру.

Упродовж XIV-XV ст. в Україні збудовано низку оборонних замків. Окремі з них збереглися дотепер. Замки переважно споруджували з дерева. Кам'яними були Кам'янець-Подільський, Хотинський, Меджибіжський, Жванецький і замки Скали, Смотрича на Поділлі й Луцька на Волині .

Важливим джерелом пізнання нашого краю в епоху Середньовіччя стали описи подорожей арабських мандрівників територією України або описані перекази наших територій з уст українських купців. Так, у розвідці Ібн-Даста “Книга добрих скарбів" (перша половина Х ст.) згадується традиційна українська гостинність, де шанують гостей і добре ставляться до чужинців, не дозволяючи нікому їх кривдити або утискати. Відома також праця арабського письменника Ібн-Хаукаля, що мандрував світом упродовж 30 років, “Книга шляхів і держав" (70-ті роки Х ст.) $)^{4}$

Значно частіше Україну відвідували европейські мандрівники, котрі подорожували зі Заходу та Півдня на Схід у XV-XVI ст. Так, Ж. де Лянуа посол Франції, Англії та Бургундії - 1421 р. побував у таких містах, як Львів, Судова Вишня, Белз, Луцьк, Кам'янець-Подільський, а згодом відвідав Малу Татарію (Степову Україну) і м. Кафу (Феодосію). Збереглися описи посла Венеціянської республіки А. Контаріні після його мандрівки в 1437 р. Україною, Грузією, Московією. Географічне положення України добре описав відомий німецький дипломат 3. Герберштайн, “дорадник чотирьох цісарів”.

Один із найдокладніших описів козацької України - щоденник подорожі П. Алеппського, який відвідав наші землі в 1654 і 1656 pp. Він змальовує нашу Батьківщину прекрасною країною, що “повна мешканців і замків, мов гранатне яблуко зерен”. Зацікавленість Україною европейцями зростала. Це підтверджує "Опис України", що зробив французький інженер Гійом де Боплан (середина XVII ст.), перебуваючи на військовій службі у польського короля. Він детально розповів про побут і звичаї українців, а його мапа тодішньої України, стала неоціненним джерелом і для сучасних історико-краєзнавчих студій.

Важливу складову туристичної сфери становить інфраструктура, зокрема готельне господарство, тому доцільно простежити історію його розвитку в Україні. Праобразом перших готелів у Руси-Україні були заїжджі двори, розташовані один від одного на відстані кінного переходу. У великих містах споруджували гостинні

\footnotetext{
${ }^{3}$ Iсторія господарства: Украӥна і світ: підручник, ред. Богдан Лановик, (Тернопіль, 1997), 74-80.

${ }^{4}$ Там само, $55-57$.
} 
двори, які, крім об'єктів розміщення та харчування, мали крамниці, склади. Такі споруди від XV ст. створювали при поштових станціях, а також на торговельних шляхах, котрими проходили купецькі каравани з Польщі, Кримського Ханства, Туреччини, Молдови, Вірменії, Угорщини та країн Західної Европи.

Отже, навіть загальнооглядова інформація про туристичну Україну в перший період розвитку туризму підтверджує, що інтерес мандрівників до наших просторів постійно зростав, а залишені ними матеріяли з описом території України та людей, які ії заселяли, $є$ неоціненним скарбом для краєзнавчого вивчення історії краю.

Другий етап розвитку туризму в Україні та світі (початок XIX - 10-ті роки XX ст.), пов'язаний із розвитком індустріяльного суспільства, сприяв перетворенню стихійного мандрівництва на організований туризм. Специфікою України було те, що вона, як і в попередні чотири століття, залежала від геополітичних територіяльних сусідів: на початку XX ст. - від двох великих імперських держав - Росії й Австрії. Тому характер туризму дуже нагадував процеси, що відбувалися у згаданих імперіях загалом: поступово розвивалися транспортна інфраструктура, музейна справа, споруджувалися готелі. На межі XIX-XX ст. прогресувало краєзнавство. Основною причиною такого поступу став загальноевропейський процес науково-технічного поступу та пришвидшений на його базі соціяльно-економічний розвиток України.

У туристичній сфері спостерігався достатньо бурхливий розвиток міжнародного туризму. Це зумовило створення в 1898 р. першої міжнародної туристичної організації - Міжнародної ліги туристичних організацій. Штабквартира була розташована у Люксембурзі.

Першим великим готелем Києва того періоду дослідники вважають “Зелену гостинницю”. Готель збудований у 1803-1805 pp. і належав Києво-Печерській лаврі. На межі XIX-XX ст. Київ уже мав стільки місць у готелях, що їх цілком вистачало для заможних туристів.

3 утворенням "Підприємства громадських подорожей в усі країни світу", створеного у Петербурзі 1885 р., почали виникати подібні організації в інших містах імперії, наприклад, в Одесі - Кримський гірський клуб (1890) із філіями в Ялті й Севастополі, а 1895 р. - Ялтинське екскурсійне бюро. У 1901 р. виникло Російське товариство туристів із філіями в Києві, Харкові, Полтаві, Катеринославі, Кам'янці-Подільському, Одесі. Воно у перші роки діяльности вступило до Міжнародної ліги туристичних товариств.

На західноукраїнських землях кінець ХIX ст. - це освоєння туристичних територій Яремча, Ворохти, Гребенева й інших місць, а вже на початку XX ст. розгорнувся масовий туристичний рух, що дав підстави вченому В. Кубійовичу констатувати про туризм як один із визначальних напрямів господарської спеціялізації Карпат 5 .

\footnotetext{
${ }^{5}$ Володимир Кубійович, Туристика в Карпатській Украӥні. (1939), 4-8.
} 
ISSN 2078-6077. Наукові зошити історичного факультету Львівського університету. 2018-2019. Випуск 19-20. Proceedings of History Faculty of Lviv University. 2018-2019. Issue 19-20.

До галицького туризму важливу сторінку вписали численні туристичні, краєзнавчі й спортові товариства. Туристичною діяльністю зацікавилися українські товариства “Сокіл” і “Чорногора" (1910), польське товариство “Татранське”. Усі вони надавали методичну та практичну допомогу проводити міжнародні мандрівки, спрямовані на пізнання Карпат, Альп, Татр. Однак еволюційний поступ туризму перервала Перша світова війна.

У третій міжвоєнний період розвитку туризму в Україні туристичнокраєзнавча робота на західноукраїнських землях, завойованих тоді Польщею, швидко відновилася. Професор I. Крип'якевич у 1921 р. заснував “Кружок любителів Львова”. За його допомогою організовували перші науково-пізнавальні мандрівки Львовом та його околицями. У 1922 р. відновило роботу туристичне товариство "Чорногора".

Вагомий внесок у розвиток туризму зробило краєзнавче українське туристичне товариство “Плай”, зорганізоване 1924 р. у Львові. Воно популяризувало пам'ятки природи та культури, розробляло туристичні маршрути рідним краєм. У такому ж напрямі діяли товариства “Сокіл”, “Січ”, “Луг” та ін.

У 30-х роках почали зароджуватися перші об'єкти туристичної інфраструктури - захисти, які чимось нагадували сучасні турбази. З'явилися дитячо-юнацькі пластові табори й агрооселі - літниська для самодіяльних туристів, що формувалися з патріотичної української інтелігенції.

У Центральній та Східній Україні, які ввійшли до складу СРСР, туристична справа розвивалася по-іншому. Так, у 20-х роках система туристичноекскурсійних закладів формувалася на засадах національно-культурного відродження. Натомість у період сталінського деспотизму, що утвердився в Україні наприкінці 20-х років XX ст., вона зазнала грубого ідеологічного впливу партійних і державних органів. Хоча зауважимо: у 20-х роках були відкриті перші будинки відпочинку. В 1928 р. засновано Одеський науково-дослідний інститут курортології, який розпочав вивчати рекреаційні ресурси України, щоб використовувати їх для лікування.

Управління туризмом в Україні підпорядковувалося Товариству пролетарського туризму, створеному в РРФСР. В Україні діяло його відділення.

У 1930 р. виникло Всесоюзне добровільне товариство пролетарського туризму та екскурсій. У середині 30 -х років його, як і всі інші добровільні туристичні товариства, що існували в Україні, ліквідували на підставі постанови уряду. Водночас організацію туризму та екскурсій передали Всесоюзній центральній раді професійних спілок.

Після завершення Другої світової війни, яка відчутно зашкодила туристичній інфраструктурі, Україна ввійшла у четвертий етап світового розвитку туризму.

Туризм в Україні ще довго перебував у занепаді. Лише в 60 -х роках держава виявила інтерес до його подальшого розвитку, зокрема тоді, коли в 1965 р. на рівні областей були створені профспілкові ради з туризму та екскурсій. Туризм 
в Україні продовжував розвиватися на профспілковій та відомчій основі. Профспілковим туризмом керував “Укрпрофтуризм", а чужоземним монопольно займалися "Інтурист” i “Супутник”, який відповідав за розвиток міжнародного молодіжного туризму.

Від 70-х років туризм в Україні поступово перетворюється на галузь сфери послуг із достатньо розвинутою інфраструктурою. Однак найбільший недолік туристичної сфери полягав у безпосередньому втручанні в їх діяльність керівних органів комуністичних і профспілкових організацій.

Починаючи з кінця 80-х і в перші роки незалежности молода Українська держава зіткнулася з чималими труднощами у розбудові власної туристичної галузі - погіршувалася матеріяльно-технічна база туризму, кошти відпливали за кордон. Унаслідок цього в 1989-1992 рр. держава втратила майже 80 \% валютних надходжень від чужоземного туризму 6

Важливий крок у створенні правових засад туристичної діяльности та його розвитку - прийняття Верховною Радою України 15 вересня 1995 р. Закону України "Про туризм".

На початку XXI ст. туристична галузь практично відновила попередні потужності й почала відігравати важливу роль в економічній діяльності України, виробляючи до 8 \% ВВП і склавши 20 \% зовнішньоторговельного обігу України. Туристична галузь забезпечила роботою 1,58 млн українців ${ }^{7}$. Цей період дослідники Мукачівського державного університету назвали транснаціоналізацією туристичної сфери. Простежується нова форма економічної та політичної взаємодії різнополярного світу, внаслідок чого капітал концентрувався на розвитку міжнародного туризму ${ }^{8}$.

Туристична діяльність в Україні тісно поєднана з наявністю ресурсної бази, що становить основу для поступу рекреаційного туризму, пов'язаного 3 лікуванням, відпочинком, оздоровленням. Вирізняють бальнеологічні (запаси мінеральних вод), бальнеогрязеві (запаси грязей), фітолікувальні (масиви лісових і паркових насаджень), біотичні (рекреаційні ліси, ботанічні, ентомологічні, іхтіологічні, орнітологічні, ботанічні й зоологічні пам'ятки природи, ботанічні сади та зоопарки).

3 метою розвитку відпочинкового (оздоровчого) туризму Україна використовує сприятливі кліматотерапевтичні умови, привабливі ландшафти: гірські, рівнинні, морські й річкові. Вагому цінність становлять національні природні парки, заповідники та заказники. Особливу роль у розвитку лікувального туризму відіграють мінеральні води. За чинною класифікацією, їх розподіляють на вісім основних бальнеологічних груп: 1) мінеральні води без специфічних

${ }^{6}$ Ігор Смирнов, Логістика туризму: навч. посіб. (Київ: Знання, 2009), 229.

7 Там само, 245.

${ }^{8}$ Ольга Мілашовська, Тетяна Лужинська, Ганна Чубірка, Основні аспекти розвитку міжнародного туризму в контексті процесів глобалізаиії. (Луцьк: РВВ Луцького НТУ, 2016), 326. 
ISSN 2078-6077. Наукові зошити історичного факультету Львівського університету. 2018-2019. Випуск 19-20. Proceedings of History Faculty of Lviv University. 2018-2019. Issue 19-20.

компонентів та властивостей; 2) вуглекислі; 3) сірководневі; 4) залізисті; 5) миш'якові; 6) йодобромні; 7) родонові; 8) боровмісні та слабомінералізовані з високим умістом органічних речовин. Практично в Україні виявлені майже всі групи мінеральних вод.

Основна маса підземної гідросфери України - мінеральні води без специфічних компонентів. Вони поширені майже на всій території України. Дуже цінні у лікувальному сенсі вуглекислі води. Найбільше відомих джерел цих вод зосереджено у Карпатському регіоні, зокрема в Закарпатті. Сірководневі води пов'язані з нафтогазовими відкладами. Такою територією, скажімо, $\epsilon$ Прикарпаття. Найбільше курортне значення мають дуже поширені хлоридні натрієві води. На основі цінних питних лікувальних і лікувально-столових залізистих вод діє Шаянський санаторний комплекс у Закарпатті. 3-поміж інших бальнеологічних груп поширені родонові води, переважно хлоридні киснево-азотні слабомінералізовані води неглибокої циркуляції атмосферного походження, що формуються у зонах порід тектонічного утворення (Житомирська, Вінницька, Кіровоградська, Хмельницька, Київська області). На їх базі функціонує десять лікувальних установ. Найвідоміший серед них - курорт Хмільник.

В Україні залягають рідкісні миш'якововмісні підземні води (Закарпатські миш'якові джерела). Боровмісні підземні води виявлені у Карпатах, де їх використовують і для ванн, і для внутрішнього вживання. Терапевтичні властивості цих вод визначають йонно-сольовим складом або іншими біологічно активними компонентами.

Води з високим умістом органічних сполук виявлені лише на Прикарпатті. Це два родовища "Нафтусі” - у Трускавці й Східниці.

Лікувальні грязі в Україні відомі здавна. Їх застосовують для загальних і місцевих аплікацій, грязеводяних ванн, а також у поєднанні з електропроцедурами. В Україні експлуатується сім торф'яних, десять сульфідних родовищ. Особливо місце посідають унікальні ресурси озокериту, який вважають цінним різновидом бальнеологічних ресурсів, що мають протизапальні й знечулювальні властивості. Промислові родовища озокериту розміщені на Прикарпатті - у Львівській та Івано-Франківській областях (Бориславське, Дзвиняцьке, Старунське).

Для лікувально-оздоровчих потреб в Україні все частіше використовують біошофіт (мінерал із унікальними лікувальними властивостями). Ним оздоровлюють опорно-руховий апарат, нервову та серцево-судинну системи. Промислові запаси біошофіту виявлені у Полтавській і Чернігівській областях 9 .

Значні поклади лікувальних торф'яних грязей є у Львівській (Великолюбінське родовище), Івано-Франківській (Оболонське родовище) та інших областях. 3поміж намульно-сульфідних грязей, що експлуатуються, значними запасами лікувальної сировини вирізняються Куяльницьке $(11$ млн м³), Шабалайське $\left(9,6\right.$ млн м $\left.{ }^{3}\right)$ в Одеській області та ін. Високі лікувальні властивості цих грязей

\footnotetext{
${ }^{9}$ Валентина Сапрунова, Туризм: эволюичия структуры, маркетинг. (Москва: Ось-89, 1997), 136.
} 
ISSN 2078-6077. Наукові зошити історичного факультету Львівського університету. 2018-2019. Випуск 19-20. Proceedings of History Faculty of Lviv University. 2018-2019. Issue 19-20.

формуються за рахунок сульфітів морської води, тому вони дуже популярні в Одеській групі курортів, на курорті Саки.

Високі лікувальні властивості цих грязей формуються за рахунок сульфітів морської води, тому вони дуже популярні в Одеській групі курортів, на курорті Саки.

Фітолікувальні ресурси обмежуються параметрами рекреаційного використання лісів, їх водоохоронно-захисними властивостями, цілющим впливом на організм людини і сприятливим санітарно-гігієнічним тлом для лікування, відпочинку й туризму.

Площа українських лісів державного значення, що можна застосовувати 3 метою рекреаційної діяльности, -4 млн га (за даними С. Генсірука). Комплексна оцінка лісів, проведена під керівництвом ученого, дала змогу виокремити 265 зручних для рекреаційного освоєння територій і окремих місцевостей загальною площею, яка перевищує 1 млн га.

Серед ландшафтних ресурсів особливе місце належить горам. Розмаїття природних ландшафтів, наявність екстремальних, вигідних і комфортних умов сприяють розвитку різних видів туризму - від екстремальних і спортивних до оздоровчих та санаторно-лікувальних.

Гірськорекреаційні туристичні ресурси нашої держави переважно зосереджені у Карпатах і в Криму.

Високоатрактивне для розвитку спелеотуризму є Поділля з унікальними $\mathrm{i}$ найдовшими в Европі карстовими печерами (Борщівський район Тернопільщини). Усе більшого значення набуває Полісся, зокрема Західне, з озерними, річковими та лісовими ландшафтами.

Значний природоохоронний резерв держави становлять біосферні заповідники (площа -240 тис. га), 16 природних заповідників, 29 національних парків.

Серед пляжних ресурсів особливе місце займають ресурси, які зосереджені у приморських територіях Одеської, Миколаївської, Херсонської, Запорізької та Донецької областей та у Криму. Рекреаційна цінність морського узбережжя визначається поєднанням сприятливих кліматичних, бальнеологічних i ландшафтних ресурсів. Для рекреаційного туризму можна використовувати близько 1500 км морського берега різного типу.

До групи пізнавальних ресурсів належать пам'ятки історії, історикоархітектурні пам'ятники, пам'ятки сучасної архітектури, унікальні споруди культури, спорту, ремесла, пам'ятки фольклору тощо.

Україна багата на пізнавальні ресурси, які є надійною базою для розвитку i внутрішнього, і міжнародного туризму, хоч їх розміщення і структура дуже часто мають регіональну специфіку. Так, Центральна й Східна Україна багата на історичні пам'ятки, пов'язані зі зародженням і розвитком української історії та культури. Натомість південь $€$ територією, де виявлено чимало пам'яток античної культури, а західна частина України вирізняється етнічними особливостями, пам'ятками фольклору, народної архітектури тощо. Такі об'єкти приваблюють 
ISSN 2078-6077. Наукові зошити історичного факультету Львівського університету. 2018-2019. Випуск 19-20. Proceedings of History Faculty of Lviv University. 2018-2019. Issue 19-20.

туристів незалежно від сезону й пори року, що має неабияке значення, щоб активізувати туристичну діяльність.

Серед міжнародних і внутрішніх туристів особливо популярними вважаються фортифікаційні споруди - Білгород-Дністровська, Судацька, Хотинська, Кам'янець-Подільська фортеці, музеї, зокрема Київський і Львівській скансени (просто неба). Українське бароко - своєрідний напрям архітектури (Київ, Чернігів, Ніжин).

Розвиток міжнародного туризму в Україні, попри надійну ресурсну базу, характеризується певною нестабільністю. Так, у 2010 р. сюди прибули 21 203,3 тис. осіб, у 2015 р. - 12 428,3, або на 69,9 \% менше. Натомість через два роки ситуація дещо покращилася, і в 2017 р. нашу країну відвідало 14 229,6 тис. осіб. Це більше на 12,7 \% порівняно з 2015 р., але значно менше, ніж у 2010 р (табл. 1). Такі коливання останніх років пояснюються нестабільністю економічної, а передусім - політичної ситуації. Особливо негативно впливає на імідж України російсько-українська війна на Донбасі й анексія Криму.

Якщо аналізувати міжнародні поїздки чужоземних громадян в Україну за метою (див. табл. 1), то найбільша кількість людей прибула з приватною ціллю. Причому громадян, котрі приїжджають в Україну, зменшується за згадуваний період. Хоча відносна їх величина навіть збільшується: 2010 р. вона становила 90,0 \%, 2015 p. - 92,7 \%, 2017 р. - 96,6 \% щодо абсолютних показників. У структурі мети поїздок за останні роки зменшилася частка відвідувань 3 особистою, службовою, діловою і дипломатичною ціллю, а також організованих туристів - із 1083,0 тис. у 2010 р. до 39,0 тис. у 2017 р.

Таблиия 1

В’їзд чужоземних громадян в Україну за метою поїздки 2010, 2015, 2017 рр.

\begin{tabular}{|c|c|c|c|c|c|c|c|c|c|c|c|c|c|c|c|c|}
\hline \multirow{3}{*}{ Роки } & \multirow{2}{*}{\multicolumn{2}{|c|}{$\begin{array}{c}\text { Кількість } \\
\text { чужоземних } \\
\text { громадян, які } \\
\text { в'їх али в } \\
\text { Україну } \\
\end{array}$}} & \multicolumn{14}{|c|}{ Із них за метою поїздки } \\
\hline & & & \multicolumn{2}{|c|}{$\begin{array}{c}\text { органі- } \\
\text { зований } \\
\text { туризм }\end{array}$} & \multicolumn{2}{|c|}{\begin{tabular}{|c|} 
службова, \\
ділова, \\
дипломатич \\
на
\end{tabular}} & \multicolumn{2}{|c|}{ прива тна } & \multicolumn{2}{|c|}{ нав чання } & \multicolumn{2}{|c|}{$\begin{array}{c}\text { пра це- } \\
\text { влашту- } \\
\text { в ання }\end{array}$} & \multicolumn{2}{|c|}{ імміграція } & \multicolumn{2}{|c|}{$\begin{array}{c}\text { куль- } \\
\text { турний } \\
\text { туризм }\end{array}$} \\
\hline & 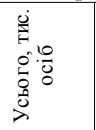 & $\%$ & 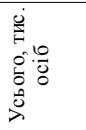 & $\%$ & 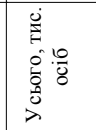 & $\%$ & 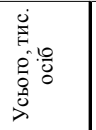 & $\%$ & 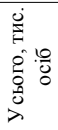 & $\%$ & 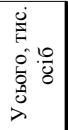 & $\%$ & 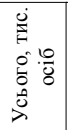 & $\%$ & 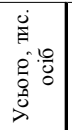 & $\%$ \\
\hline 2010 & 21203,3 & 100 & 1083,0 & 5,1 & 694,5 & 3,3 & 19089,1 & 90,0 & 67,6 & 0,3 & 14,8 & 0,1 & 48,3 & 0,2 & 206,1 & 1,0 \\
\hline 2015 & 12428,3 & 100 & 137,9 & 1,1 & 41,2 & 0,3 & 11525,2 & 92,7 & 0,1 & 0,0 & 1,3 & 0,0 & 2,3 & 0,1 & 720,3 & 5,8 \\
\hline 2017 & 14229,6 & 100 & 39,0 & 0,3 & 89,0 & 0,6 & 13741,6 & 96,6 & 4,5 & 0,0 & 2,6 & 0,0 & 4,0 & 0,0 & 348,9 & 2,5 \\
\hline
\end{tabular}

Покраїнний аналіз міжнародних прибуттів в Україну засвідчує, що географія країн розширюється. Наприклад, у 2010 р. нашу державу відвідало 117 країн, а вже у 2017 р. -127. За кількістю відвідин України у 2017 р. найперше виділяються країни-сусіди, зокрема Молдова, Білорусь, Польща, Російська Федерація, які разом становили понад 70 \% від загальної кількости громадян, що в’їхали в Україну (рис. 1). 


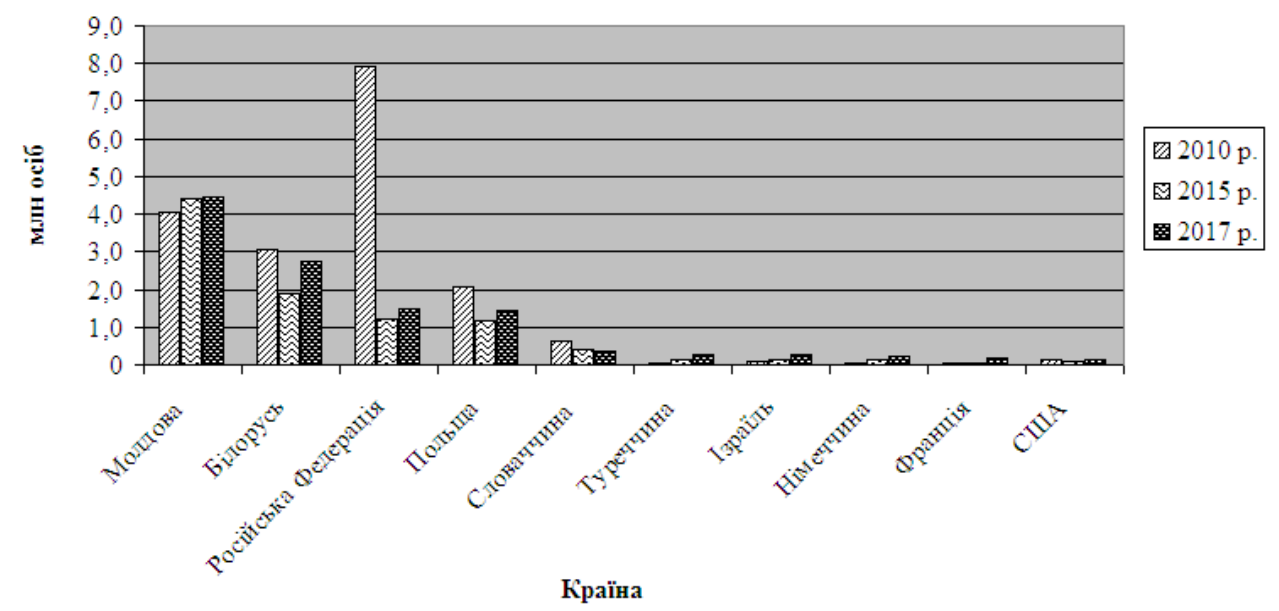

Рис. 1. Перші десять країн за кількістю чужоземних громадян, які відвідали Україну в

$$
2010,2015,2017 \text { pp. }
$$

Російська Федерація, починаючи від 2015 р., за кількістю в”їзних в Україну туристів поступилася Молдові, Білорусі (рис. 1). Причиною цього стала розв'язана Росією війна на сході України й анексія Криму (2014р.).

До першої десятки за кількістю чужоземних відвідувачів, окрім зазначених чотирьох країн-сусідів, ввійшли Словаччина, Туреччина, Ізраїль, Німеччина, Франція та США. На перші десять країн, за даними Держприкордонслужби України, припадає 73,7 \%, або майже $3 / 4$ від загальної кількости міжнародних туристів, котрі прибули в Україну 2017 р. (див. рис. 1).

Найпривабливішими центрами, територіями для чужоземних туристів $€$ міста Київ, Львів, Одеська і Львівська області.

Чужоземні громадяни, які відвідують Україну, в середньому перебувають чотири дні, й кожен із них витрачає приблизно 600 дол. США ${ }^{10}$.

Міжнародний туризм, пов'язаний з виїздом українських громадян в інші країни світу, за даними Адміністрації Держприкордонслужби, засвідчує, що за останні роки їх кількість зростає (табл. 2). За останніх 17 років вона збільшилася 3 13422,0 тис. осіб у 2000 р. до 26 437,4 тис. осіб у 2017 р., або на 97,0 \%, тобто майже у два рази. Здавалося би, це - позитивне явище, спричинене потребою провести вільний час за межами своєї держави. Однак статистичні дані вказують, що кількість організованих туристичних поїздок зменшується: 2010 р. їх налічувалося 1275,4 тис. осіб, 2015 р. - 206,6, а у 2017 р. - усього 120,9 тис. осіб. Натомість кількість приватних поїздок зросла за відповідний період від 15 038,6 тис. осіб і 22 749,9 до 26219,3 тис. осіб.

\footnotetext{
${ }^{10}$ Валентин Федорченко, Тетяна Дьорова, Історія туризму в Україні: навч. посіб. (Київ: Вища школа, 2002), 181.
} 
ISSN 2078-6077. Наукові зошити історичного факультету Львівського університету. 2018-2019. Випуск 19-20. Proceedings of History Faculty of Lviv University. 2018-2019. Issue 19-20.

Основною причиною, що кількість організованих туристичних поїздок за кордон зменшується, $є$ зниження добробуту населення. За показниками приватних поїздок, які невпинно зростають, приховується, на наш погляд, потреба працевлаштуватись та підвищити власний добробут. Цю тезу дещо підтверджують показники кількости виїздів у чужоземні країни. Так, кількість поїздок у сусідню Польщу, де успішно працевлаштовуються українці, зросла від 4,0 млн осіб у 2010 р. і 9,5 у 2015 р. майже до 10 млн. осіб у 2017 р. (табл. 3, рис. 2).

Табличя 2

Виїзд громадян України за кордон у 2010, 2015, 2017 рр., тис. осіб

\begin{tabular}{|c|c|c|c|c|}
\hline \multirow{2}{*}{ Роки } & \multirow{2}{*}{$\begin{array}{c}\text { Кількість виїздів } \\
\text { за межі України }\end{array}$} & \multicolumn{3}{|c|}{ Із них за метою поїздки } \\
\cline { 3 - 5 } & & Службова & $\begin{array}{c}\text { Організований } \\
\text { туризм }\end{array}$ & Приватна \\
\hline 2000 & 13422,3 & - & - & - \\
\hline 2005 & 16453,7 & - & - & - \\
\hline 2010 & 17180,0 & 866,0 & 1275,4 & 15038,6 \\
\hline 2015 & 23141,6 & 185,2 & 206,6 & 22749,9 \\
\hline 2017 & 26437,4 & 97,3 & 120,9 & 26219,3 \\
\hline
\end{tabular}

Таблиия 3

Перші десять країн за кількістю виїзних туристів з України в 2010, 2015, 2017 рр., тис. осіб

\begin{tabular}{|c|l|c|c|c|}
\hline \multirow{2}{*}{ № 3/п } & \multirow{2}{*}{ Країни } & \multicolumn{3}{|c|}{ Роки } \\
\cline { 3 - 5 } & & 2010 & 2015 & 2017 \\
\hline 1 & Польща & 3999,6 & 9505,7 & 9991,0 \\
\hline 2 & Російська Федерація & 5233,9 & 4080,4 & 4376,4 \\
\hline 3 & Угорщина & 1789,3 & 2442,1 & 3118,8 \\
\hline 4 & Молдова & 1889,7 & 1727,3 & 1680,4 \\
\hline 5 & Білорусь & 1358,1 & 1325,5 & 1186,5 \\
\hline 6 & Туреччина & 4590,1 & 510,5 & 1185,0 \\
\hline 7 & Румунія & 503,2 & 678,7 & 1045,4 \\
\hline 8 & Словаччина & 384,0 & 755,2 & 854,7 \\
\hline 9 & Сгипет & 328,6 & 350,9 & 733,6 \\
\hline 10 & Німеччина & 383,3 & 294,8 & 344,2 \\
\hline
\end{tabular}




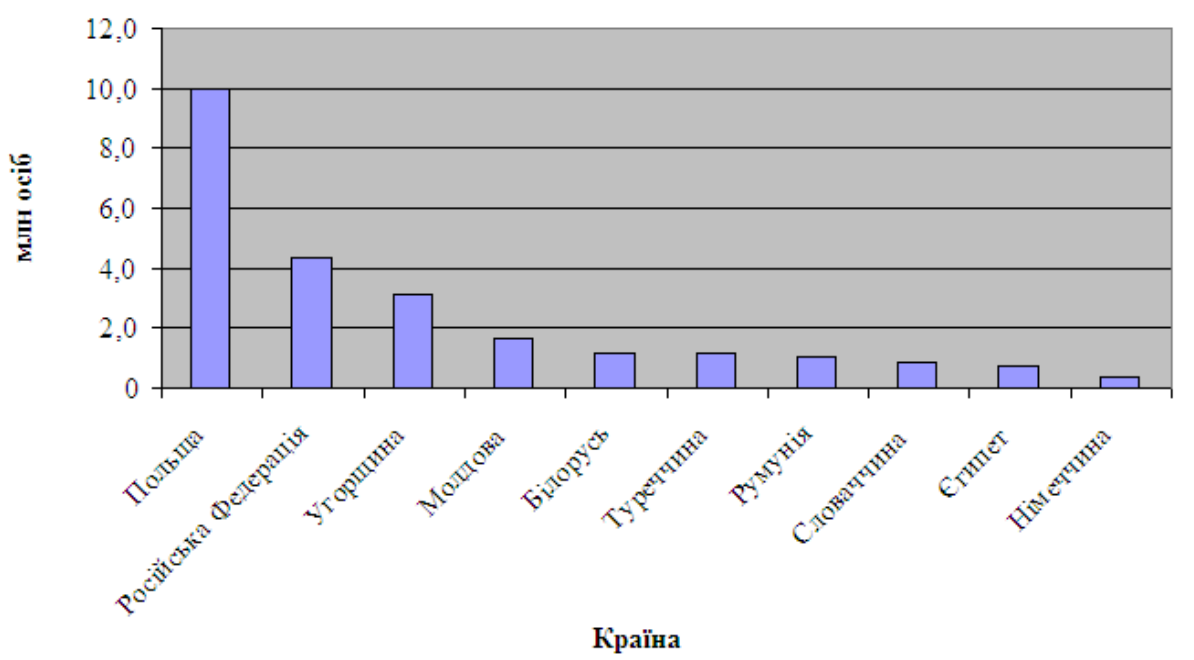

Рис. 2. Перші десять країн за кількістю виїзних туристів з України, 2017 р.

Таблиия 4

Туристичні потоки України, осіб

\begin{tabular}{|c|c|c|c|c|c|c|}
\hline \multirow[b]{2}{*}{ Роки } & \multirow[b]{2}{*}{ 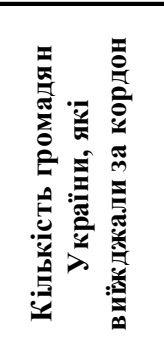 } & \multirow[b]{2}{*}{ 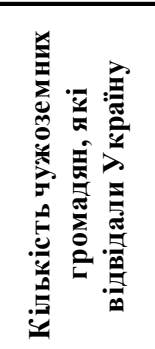 } & \multirow[b]{2}{*}{ 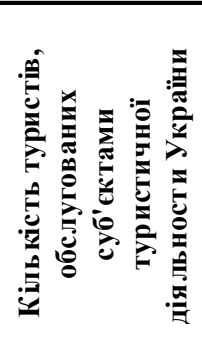 } & \multicolumn{3}{|c|}{ У тому числі } \\
\hline & & & & 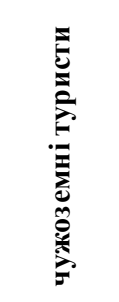 & 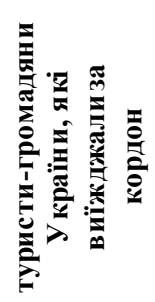 & 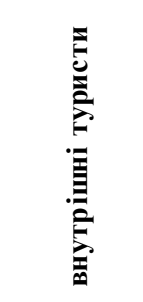 \\
\hline 2000 & 13422320 & 6430940 & 2013998 & 377871 & 285353 & 1350774 \\
\hline 2001 & 14849033 & 9174166 & 2175090 & 416186 & 271281 & 1487623 \\
\hline 2002 & 14729444 & 10516665 & 2265317 & 417729 & 302632 & 1544956 \\
\hline 2003 & 14794932 & 12513883 & 2856983 & 590641 & 344332 & 1922010 \\
\hline 2004 & 15487571 & 15629213 & 1890370 & 436311 & 441798 & 1012261 \\
\hline 2005 & 16453704 & 17630760 & 1825649 & 326389 & 566942 & 932318 \\
\hline 2006 & 16875256 & 18935775 & 2206498 & 299125 & 868228 & 1039145 \\
\hline 2007 & 17334653 & 23122157 & 2863820 & 372455 & 336049 & 2155316 \\
\hline 2008 & 15498567 & 25449078 & 3041655 & 372752 & 1282023 & 1386880 \\
\hline 2009 & 15333949 & 20798342 & 2290097 & 282287 & 913640 & 1094170 \\
\hline 2010 & 17180034 & 21203327 & 2280757 & 335835 & 1295623 & 649299 \\
\hline 2011 & 19773143 & 21415296 & 2199977 & 234271 & 1250068 & 715638 \\
\hline 2012 & 21432836 & 23012823 & 3000696 & 270064 & 1956662 & 773970 \\
\hline 2013 & 23761287 & 24671227 & 3454316 & 232311 & 2519390 & 702615 \\
\hline 2014 & 22437671 & 12711507 & 2425089 & 17070 & 2085273 & 322746 \\
\hline 2015 & 23141646 & 12428286 & 2019576 & 15159 & 1647390 & 357027 \\
\hline 2016 & 24668233 & 13333096 & 2549606 & 35071 & 2060974 & 453561 \\
\hline
\end{tabular}


ISSN 2078-6077. Наукові зошити історичного факультету Львівського університету. 2018-2019. Випуск 19-20. Proceedings of History Faculty of Lviv University. 2018-2019. Issue 19-20.

Збільшив кількість виїзних потоків громадян з України безвізовий режим до країн Шенгенської зони від 2017 р.

Аналіз туристичних потоків країни у 2010-2017 рр. (табл. 4) засвідчує, що кількість громадян України, які виїжджали за кордон, і кількість чужоземців, котрі відвідували Україну, мають тенденцію зростати. Щоправда, у період загострення політичної ситуації - Революції Гідности, анексії Криму та інтервенції Російської Федерації на Донбас (2014) - кількісні показники туристичних потоків різко зменшилися. Особливо це позначилося на відвідуванні України. Так, за цим показником кількість чужоземних громадян у 2014 р. зменшилася майже удвічі. Зате кількість виїздів громадян України за кордон, починаючи від 2015 р., зростала і досягнула у 2017 р. 26,4 млн осіб.

У структурі туристичних потоків, обслужених туроператорами і турагентами, спостерігається тенденція росту. Однак, це відбувається не за рахунок чужоземних туристів і навіть не за внутрішніх, а внаслідок зростання кількости туристів - громадян України, які виїжджали за кордон. Їх кількість за останніх 17 років (2000-2017 рр.) щорічно становила від 2,1 до 2,8 млн осіб. Безсумнівно, держава зацікавлена у розвитку в 'їзного туризму, оскільки він належить до важливих джерел збільшення валютних надходжень. Тому туристичне господарство країни, зокрема ії інфраструктура, повинна так розвиватися, щоби максимально задовольняти і чужоземних, і внутрішніх туристів.

Україна як держава із потужним ресурсним потенціялом має всі можливості у найближчому майбутньому стати конкурентоспроможною на світовому туристичному ринку.

\title{
THE DEVELOPMENT OF INTERNATIONAL TOURISM IN UKRAINE FROM THE BEGINNING TO THE PRESENT TIME
}

\author{
Stepan KUZYK \\ Ivan Franko National University of Lviv, \\ Department of Economic and Social Geography \\ Doroshenka str. 41, 79000, Lviv, Ukraine \\ e-mail: borsukurij2@gmail.com
}

Tourism in Ukraine has undergone a long period of development - from the birth of a prototype of international tourism dating back to the early Middle Ages to organized mass tourism of the XX-XXI century. The existing resource base contributes to further development of international tourism in Ukraine. An important means of developing international tourism are cognitive resources (historical attractions, architectural attractions, unique buildings of culture, crafts, and attractions of folklore).

Further improvement of the tourist infrastructure gives grounds to state about the high potential of development of both domestic and international tourism in Ukraine.

Among the landscape resources a special place belongs to the mountains. The diversity of natural landscapes, the presence of extreme, favorable and comfortable conditions contribute to the development of various types of tourism - from extreme and sports to health and sanatorium and therapeutic. 
Podillya is highly attractive for the development of speleotourism. It has unique and the longest karst caves in Europe (Borshchiv district of Ternopil region). Polissya, in particular the Western part of it, with lake, river and forest landscapes, is becoming more and more important.

Beach resources are concentrated in the seaside areas of Odesa, Mykolaiv, Kherson, Zaporizhzhia and Donetsk regions. Recreational value of the seaside is determined by the combination of favorable climatic, balneological and landscape resources.

The most attractive centers, territories for foreign tourists are the cities of Kyiv, Lviv, Odessa and Lviv regions.

Foreign nationals who visit Ukraine, on average, spend four days here, and each of them spends about 600 US dollars.

Ukraine as a state with a powerful and unique tourist and recreational base is competitive on the world market of tourist services.

Keywords: wandering, international tourism, tourist zoning, tourist flows.

\section{REFERENCES}

Fedorchenko, Valentyn, Tetyana Dorova. Istoriia turyzmu v Ukrayini: navchalnyi posibnyk. (Kyiv: Vyshcha shkola, 2002). 195. (in Ukrainian)

Herders, Johans Gotfrids. Herders Reisejournal. 2 Auff. (Weinheim, 1961). (in German)

Kubiyovych, Volodymyr. Turystyka v Karpatskii Ukraini. (Nasha batkivshchyna, 1939). (in Ukrainian)

Kuzyk, Stepan. Teoretychni problemy turyzmu: suspilno-heohrafichnyi pidkhid: monohrafiia. (Vydavnychyi tsentr Lvivskoho natsionalnoho universytetu imeni Ivana Franka, 2010).

Lanovyk, Bohdan. Zynovii Matysyakevych, Roman Mateyko, Istoriia hospodarstva: Ukraina i svit: pidruchnyk. (Ternopil, 1997). 480. (in Ukrainian)

Leonard J. Lickorish, Carson L. Jenkins, An introduction to Tourism. (Routledge, 1997). (in English)

Makarchuk, Stepan Arsentiyovych. Dzhereloznavstvo istoriyi Ukrainy. (Lviv: Svit, 2008). 512. (in Ukrainian)

Milashovska, Olha. Tetyana Luzhynska. Hanna Chubirka, Osnovni aspekty rozvytku mizhnarodnoho turyzmu v konteksti protsesiv hlobalizatsiyi. (Lutsk: Redaktsiynovydavnychyi viddil Lutskoho natsionalnoho tekhnichnoho universytetu, 2016). (in Ukrainian)

Saprunova, Valentyna. Turyzm: evolyutsiia struktury, marketynh. (Moskva: Os-89, 1997). 319. (in Russian)

Smal, Ihor. Turystychni resursy svitu: navchalnyi posibnyk. (Nizhyn: Vydavnytstvo Nizhynskoho derzhavnoho universytetu imeni Mykoly Hoholia, 2010). 336. (in Ukrainian)

Smyrnov, Ihor. Lohistyka turyzmu: navchalnyi posibnyk. (Kyiv: Znannya, 2009). 444. (in Ukrainian)

Ustymenko, Lesya. Istoriia turyzmu. (Kyiv: Alterpres, 2005). 320. (in Ukrainian)

Yurchenko, Svitlana. Oksana Yurchenko, Mizhnarodnyi turyzm: navchalnyi posibnyk. (Kharkiv: Kharkivskyi natsionalnyi universytet imeni Vasylya Karazina, 2016). 328. (in Ukrainian)

Zubko, Andrii Mykolayovych. Opys Rusi-Ukrayiny zakhidnoyevropeyskymy podorozhnykamy Plano Karpini ta Villenom Rubrukom (XIII st.). (Turystychnokrayeznavchi doslidzhennya, 1998). (in Ukrainian) 
